\title{
Collision of Hydrogen Molecules Interacting with Two Graphene Sheets
}

\author{
DRAGANA A. MALIVUK GAK, University of Banjaluka, \\ Faculty of Natural Sciences, Banjaluka, \\ Bosnia and Herzegovina
University of Banjaluka, \\ $S A \check{S} A$ L. NJEŽIĆ, University of Banjaluka,
Faculty of Medicine, Banjaluka, \\ Bosnia and Herzegovina
}

\author{
Professional paper \\ UDC: 539.1 \\ DOI: 10.5937/tehnika1702167M
}

It have been performed the computational experiments with two hydrogen molecules and two graphene sheets. Hydrogen - hydrogen and hydrogen - carbon interactions are described by Lennard - Jones potential. Equations of motion of the wave packet centre are solved numerically. The initial molecule velocity was determined by temperature and collisions occur in central point between two sheets. The molecules after collision stay near or get far away of graphene sheets. Then one can find what temperatures, graphene sheet sizes and their distances are favourable for hydrogen storage. It is found that quantum corrections of the molecule classical trajectories are not significant here. Those investigations of possibility of hydrogen storage by physisorption are of interest for improvement of the fuel cell systems. The main disadvantages of computational experiments are: (1) it cannot compute with very large number of $C$ atoms, (2) it is assumed that carbon atoms are placed always in their equilibrium positions and (3) the changes of wave packet width are not considered.

Key words: graphene, Lennard-Jones potential, hydrogen storage, simulation

\section{INTRODUCTION}

A great deal of scientific community today is involved in the research of the fuel cell systems as alternative sources of energy. Hydrogen storage on the nanostructure level is considered to be one of the most important factors in improving the performance and efficiency of the fuel cells. The storage capacity goals of $6.5 \%$ mass ratio and $62 \mathrm{~kg} / \mathrm{m} 3$ volume density imposed by the U.S. Department of Energy has not been achieved experimentally yet, despite intense research efforts [1]. Many methods, as theoretical as experimental, have been proposed so far, for efficient storage of molecular hydrogen for fuel cell applications. For that use, carbon - based materials have always been regarded as the most important substrates for the hydrogen storage $[2,3]$. Carbon nanotubes are the most attractive materials for that use. But, theoretical studies with various model of graphitic systems known so far,

Author's address: Dragana Malivuk Gak, University of Banjaluka, Faculty of Natural Sciences, Banjaluka, Mladena Stojanovića 2, Bosnia and Herzegovina, e-mail: draganamalivuk@yahoo.com

Paper received: 25.01.2017.

Paper accepted: 16.03.2017. failed to reach the elusive goal.

Recently produced mono and double layer sheets of graphite - graphene, revealed some exquisite properties, awaking the hope that with these nano-objects the expected storage capacity could be reached. Graphene is crystalline allotrope of carbon with two dimensional properties. Carbon atoms in graphene are densely packed in hexagonal pattern. Each atom has four bonds, one $\sigma$ bond with each of its three neighbors and one $\pi$ bond that are oriented out of plane. The atoms are about $0.142 \mathrm{~nm}$ apart [4]. Graphene is the only form of carbon in which every atom is available for chemical reaction from two sides. Graphene has the highest ratio of edge atoms of any allotrope. Defects within a sheet increase its chemical reactivity [5]. The theoretical prediction can be realized by optimizing the structures of nano - graphite platelets [6]. The most important performance of graphene is that is lightweight, cheap, chemically inert, and environmentally benign.

One of the main problems related to graphene's the problem with growing graphene on certain surfaces. Strong interactions with the surface on which it was grown always prevent the true properties of graphene being measures experimentally. 


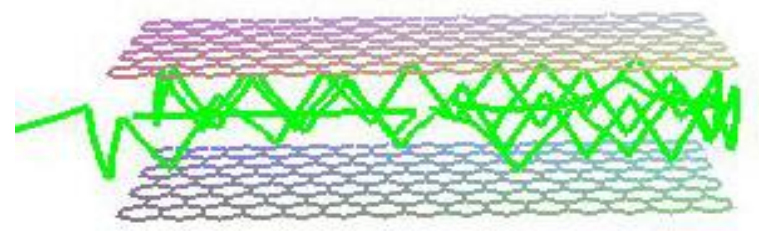

Figure 1 - The hydrogen molecules trajectories between two graphene sheets.

\section{METHOD}

By using the simplified model of motion as well as the interaction of hydrogen molecules, in this paper will be presented study of the influence of temperature, graphene layer separation and the graphene structure size on the physisorption. It is also estimated how strong the quantum effect is by comparing the classical equation of motion and equation of motion with the quantum correction - approximate quantum Newton equation.

It have been performed the computational experiments with two hydrogen molecules and two graphene sheets. Hydrogen - hydrogen and hydrogen carbon interactions are described by Lennard - Jones potential [7]. The Lennard - Jones potential (1) (also termed the L-J potential) is a mathematically simple model that approximates the interaction between a pair of neutral atoms or molecules.

$$
V=4 \varepsilon\left[(\sigma / r)^{12}-(\sigma / r)^{6}\right]
$$

Here, $\varepsilon$ is the depth of the potential well, $\sigma$ is the finite distance at which the inter-particle potential is zero, and $r$ is the distance between the particles.

Also, it is numerically solved equations of motion of the wave packet centre [8]. The initial molecules velocities are determined by temperature and collisions occur in central point between two sheets. The molecules after collision stay near or get far away graphene sheets.

Then one can find what temperatures, graphene sheet sizes and their distances are favorable for hydrogen storage. Hydrogen molecules are interacting mutually and with carbon atoms in graphene sheets.

The interactions are determined by solving the approximate Newton quantum equation (ANQE) given by

$$
\frac{d^{2} \eta}{d t^{2}}=-\frac{\partial U}{\partial \eta}-\frac{1}{8} \frac{\partial^{3} U}{\partial \eta^{3}} \sigma^{2}
$$

where $\eta=x, y, z$ are the radius vector components of the molecule wave packet center, $U$ is potential energy of interaction approximated by the L-J potential, and $\delta$ is the width of the molecule wave packet assumed to be constant. Placing $\delta=0$ in $\mathrm{ANQE}$, this equation reduces to ordinary Newton equation of motion. Varying the number of carbon atoms comprising the sheets $\left(N_{\mathrm{C}}=2 N \mathrm{x} 4 N\right)$, distance between the sheets $d$ and initial velocities determined by the temperature $T$, it could be obtain three different regions in which the behavior of hydrogen molecules is quite distinctive.

\section{RESULTS}

Results of numerical simulations are presented here.

For certain values of the parameters in the numerical simulations $(N, d, T)$ the hydrogen molecules can remain close to the graphene sheet specified period of time or to immediately put away the graphene sheet. On the figure 2 it is presented: a) hydrogen molecules get far away after collision, b) hydrogen molecules stay near the graphene sheets after collision.

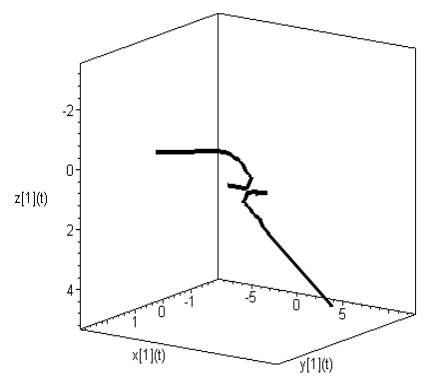

Figure 2a-After collision two molecules get far away from the sheets, at the temperature of $T=$ $700 \mathrm{~K}, N=9, d=7 a, a=0.142 \mathrm{~nm}$ and $\delta=0$.

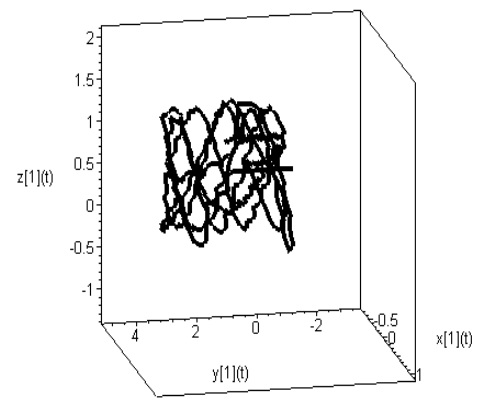

Figure $2 b$-After collision two molecules stay near the graphene sheets, at the temperature of $T=210$ $K, N=9, d=7 a, a=0.142 \mathrm{~nm}$ and $\delta=0$.

Also, it has been investigated how strong is quantum influence on the hydrogen molecules behavior in those experiments. It was found that quantum correction have no significant influence on hydrogen behavior in these cases. On figures $3 a$ and $3 b$ it can be seen trajectories of hydrogen molecules with (red line) and without (black line) quantum correction. For all the results presented here it was checked quantum correction. It is found that quantum corrections of the molecule classical trajectories are not significant here. 


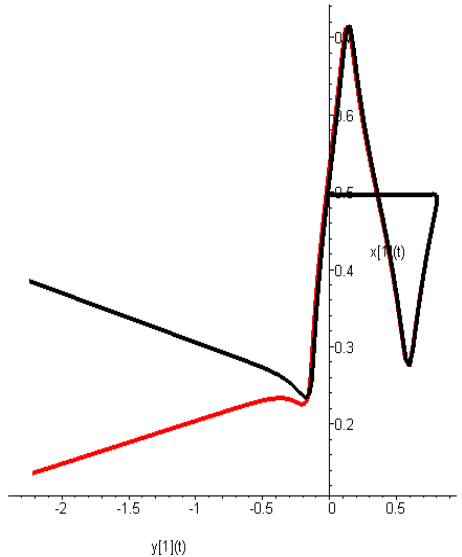

Figure $3 a$ - Classical (black line) and quantum (red line) trajectories of the molecule at: $T=500 \mathrm{~K}$, $N=4, d=7 a, a=0.142 \mathrm{~nm}, x(0)=d / 2, y(0)=$ $0, z(0)=(3 N-2) a / 4$.

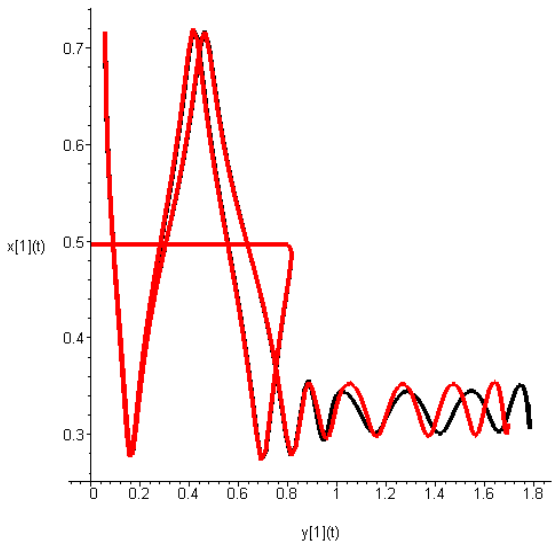

Figure $3 b$ - Classical (black line) and quantum (red line) trajectories of the molecule at: $T=600 \mathrm{~K}$, $N=4, d=7 a, x(0)=d / 2, y(0)=0, z(0)=(3 N-$ 2)a/4.

Main results are presented on figures $4 \mathrm{a}, 4 \mathrm{~b}$ and $4 \mathrm{c}$. After a large number of numerical simulations in which the observed term storage of hydrogen molecules near the graphene sheets, it was found three different regions in which the behavior of the hydrogen molecule is very specific.

In the region $\mathrm{A}$ hydrogen molecules after collision stay near graphene sheets. In the region $C$ hydrogen molecules after collision get far away from graphene sheets, and in region $\mathrm{B}$, both cases are possible, because hydrogen molecules after the collision, were only briefly located in the proximity of graphene sheet.

At fixed values of sheet distance $d$, it could be seen those three regions in temperature versus number of carbon atoms which comprise graphene sheets (figure $4 \mathrm{a}$ and $4 \mathrm{~b})$.

Also, it can be seen for the fixed temperature of $300 \mathrm{~K}$, domains which are favorable for hydrogen storage, obtained by varying distance between graphene sheets $d$ and number of carbon atoms $N$ (figure 4c).

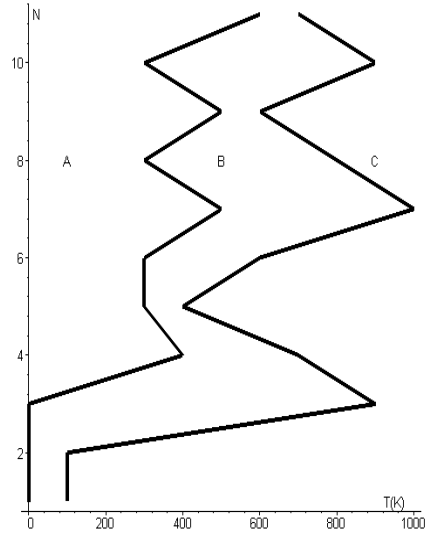

Figure $4 a-d=7 a, a=0.142 \mathrm{~nm} \delta=0$. Region $A$ hydrogen molecules after collision stay near graphene sheets, region $C$ - hydrogen molecules after collision get far away from graphene sheets, and in region $B$ - both cases are possible.

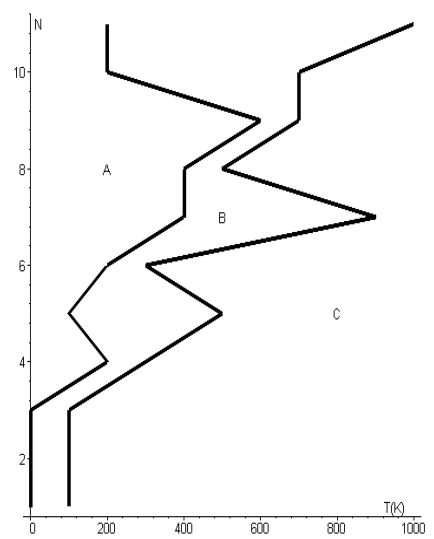

Figure $4 b-d=10 a, a=0.142 n m, \delta=0$. Region $A-$ hydrogen molecules after collision stay near graphene sheets, region $C$ - hydrogen molecules after collision get far away from graphene sheets, and in region $B$ - both cases are possible.

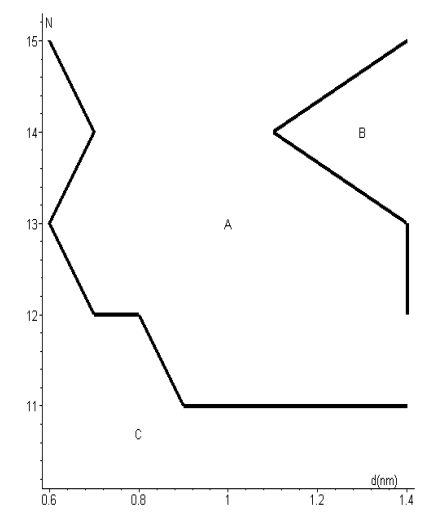

Figure $4 c-T=300 \mathrm{~K}$. Region $A$ - hydrogen molecules after collision stay near graphene sheets, region $C$ - hydrogen molecules after collision get far away from graphene sheets, and in region $B$ - both cases are possible. 


\section{CONCLUSION}

Firstly, it should be mentioned that computational experiments presented here have some shortcomings. The main shortcomings being: (1) a relatively small number of $\mathrm{C}$ atoms is considered; (2) $\mathrm{C}$ atoms are always placed in their equilibrium positions; (3) changes of the wave packet width are neglected; (4) only one molecule pair is considered, while in reality the molecule pair interacts with many other molecules.

Even in such oversimplified model it is obvious that in the most interesting temperature range - around room temperature $(300 \mathrm{~K})$ and sheet distances in the range of $0.6-1.2 \mathrm{~nm}$ there exist conditions for retaining of the hydrogen molecules between the graphene sheets. Domain A in the Fig. 4c is in agreement with Patchovski results [1], obtained by other methods. Also it was found, that quantum effects are negligible in these temperature range.

Also it would be very interesting to see how the shape of the graphene sheet affects on storage of hydrogen molecules. It is very important to find a simpler model that would allow easier theoretical research and the most effective experimental procedure for making graphene, which has the largest capacity in hydrogen storage. Investigations of possibility of hydrogen storage by physisorption are of interest for improvement of the fuel cell systems.

\section{REFERENCES}

[1] Patchkovskii S, Tse J. S, Yurchenko, S. N, Zhechkov L, Heine T. and Seifert G, Graphene nanostructures as tunable storage media for molecular hydrogen. Proceedings of the National Academy of Sciences of the United States 102: 10439-10444, 2005.

[2] Dimitrakakis G. K, Tylianakis E. and Froudakis, G. E, Pillared Graphene: A New 3-D Network Nanostructure for Enhanced Hydrogen Storage. Nano Letters 8: 3166-3170, 2008

[3] Zheckov L, Dresden: Institut fur Physikalische Chemie TU Dresden, Simulations of the Hydrogen storage capacities of carb on materials, doctoral dissertation, 2007

[4] Cooper D. R, D’Anjou B, Ghattamaneni N, Harack B, Hilke M, Horth A, Majlis N, Massicotte M, Vandsburger L, Whiteway E, Yu V, Experimental Review of Graphene, ISRN Condensed Matter Physics. International Scholarly Research Network: 1-56, 2012.

[5] Denis P. A, Iribarne F, Comparative Study of Defect Reactivity in Graphene, Journal of Physical Chemistry C 117 (37): 19048-19055, 2013

[6] Lin Y, Ding F. and Yakobson B. I, Hydrogen storage by spillover on graphene as a phase nucleation process, Physical Review B 78, 041402(R), 2008

[7] Lennard-Jones, J. E, Cohesion. Proceedings of the Physical Society 43 (5): 461-482, 1931.

[8] Jackson J. D, Classical Electrodynamics (2nd ed.), New York: John Wiley \& Sons, Inc, 1975.

\section{REZIME}

\section{SUDAR MOLEKULA VODONIKA I INTERAKCIJA SA DVA GRAFENSKA LISTA}

Predstavljeni su računarski eksperimenti sa dva molekula vodonika i dva grafenska lista. Vodonikvodonik i vodonik - ugljenik interakcija je opisana Lennard - Jones potencijalom. Jednačine kretanja centra talasnog paketa su rješene numerički. Početna brzina molekula vodonika je određena temperautrom,a sudari molekula se dešavaju u centralnoj tački između dva lista grafena. Molekuli nakon sudara mogu ostati blizu ili se udaljiti od grafenskih listova. Na osnovu ovoga se može zaključiti koje su temperature, veličine grafenskih listova i udaljenost između grafenskih listova povoljni za skladištenje voodnika. Utvrđeno je da kvantna korekcija klasičnih putanja molekula vodonika nije značajna ovde. Istraživanja mogućnosti skladištenja vodonika su od velikog značaja za unapređenje gorivnih ćelija. Glavni nedostaci ovih računarskih eksperimenata su: 1) u obzir s euzima mali broj ugljenikovih atoma, (2) pretpostavlja se da su atomi ugljenika uvijek smješteni u ravnotežni položajima, (3) promjene širine talasnog paketa nisu uzete u obzir.

Ključne reči: grafen, Lennard - Jones potencijal, skladištenje vodonika, simulacije 